\title{
CREATING DYNAMIC CAPABILITIES TO INCREASE CUSTOMER VALUE
}

\begin{abstract}
Purpose: The aim of this paper is to contribute to the strategic management literature by identifying possible combinations of three organizational capabilities (market orientation, knowledge management and customer relationship management). We also analyze the potential interaction between them that would lead to the creation of superior customer value.
\end{abstract}

Design/methodology/approach: Our research question is: 'If the customer demands superior value, how should a firm combine its existing capabilities in order to offer this superior value?'

Findings: It is clear that we should turn to dynamic capabilities to explain the connection between the interaction of these three capabilities and superior customer value. Firms are aware of the customers' demand for superior value and need to know how to combine their existing capabilities to offer this superior value.

Practical implications: We propose a possible way of increasing the value created for the customer, which is a key factor for the increasing number of firms seeking new ways to achieve and maintain competitive advantage.

Originality/value: We posit that the interaction between the three proposed capabilities constitutes a dynamic capability.

Keywords: Customer value, dynamic capabilities, market orientation, knowledge management, customer relationship management.

Paper type: Conceptual paper 


\section{INTRODUCTION}

Given the increasing intensity of business competition and the strong trend towards globalization, the attitude towards the customer is very important; their role has changed from that of a mere consumer to the role of consumer, co-operator, coproducer, co-creator of value and co-developer of knowledge and competencies (Wang, Lo, Chi and Yang, 2004). Furthermore, the complex competitive environment in which firms operate has led to the increase in customer demand for superior value (Sánchez, Iniesta and Holbrook, 2009). Therefore, more and more firms see customer value as a key factor when looking for new ways to achieve and maintain a competitive advantage (Woodruff, 1997; Woodruff and Gardial, 1996).

A firm's external and internal organizational capabilities are of vital importance for increasing the value created for the customer. Thus, a firm should focus on improving those capabilities which view the customer as its key component, in order to maximize the value created for them. We will emphasize the next three capabilities: 'market orientation' (MO), 'knowledge management' (KM) and 'customer relationship management' (CRM).

Looking within the firm, $\mathrm{KM}$ is a key capability for the creation of customer value. $\mathrm{KM}$ is important because knowledge is a key strategic resource (Grant, 1996a; Pan and Scarbrough, 1999; van den Hooff and Huysman, 2009); that is to say, if firms want to capitalize on the knowledge they possess, they must understand how knowledge is created, shared and used within the firm (Ipe, 2003). To manage knowledge effectively, firms must have an organizational culture in place that encourages its management. This culture refers to $\mathrm{MO}$, and in order to take advantage of the market-oriented culture and external knowledge simultaneously, a maintaining capability is also essential. This last capability is CRM.

From the existing literature, it can be seen that each of these three capabilities is linked to customer value. The primary aim of market-oriented firms, firms that manage their knowledge or those that manage customer relationships is to offer superior customer value. But it is not any individual or intermittent influence that is important, but rather the effect of the three capabilities has to be global and sustainable (i.e. permanent in the time). According to Sirmon, Hitt and Ireland (2007), merely possessing valuable and rare resources and capabilities does not guarantee the development of competitive advantage or the creation of value; firms must be capable of managing them effectively. It follows therefore that value can also be created by recombining existing resources and capabilities (Morrow, Sirmon, Hitt and Holcomb, 2007). It should be possible to reconfigure organizational capabilities to enable the firm to be continually creating value, and this is where dynamic capabilities come into play.

Although Liyun, Keyi, Xiaoshu and Fangfang (2008) suggest a possible relationship between these three organizational capabilities, we do not find that their theoretical justification is sufficient, and they only discuss the possible influence of this relationship on business performance. We will carry out an in-depth study of the relationship between the three capabilities, will provide further theoretical justification and will posit that this relationship contributes to increased customer value. We have not come 
across any other papers in the previous literature that deal with this relationship between the three proposed organizational capabilities, or any that consider its influence on customer value. We will address this gap in the literature by stating that customer value will be increased if there is interaction between the three proposed capabilities (MO, KM and CRM). The idea is to see how the three proposed capabilities, jointly and individually, influence customer value. We will also state that the interaction between them can constitute a dynamic capability (viewed as a 'black box') for a firm to maintain its competitive advantage. Specifically, our research question is: 'If the customer demands superior value, how should a firm combine its existing capabilities in order to offer this superior value?

In short, the aim of this paper is to contribute to the strategic management literature by identifying possible combinations of the three proposed organizational capabilities and to analyze whether the possible interaction between them leads to the creation of superior customer value.

The remainder of the paper is organized as follows: first, the theoretical context in which this paper is based is presented; second, building on the existing literature on $\mathrm{MO}, \mathrm{KM}, \mathrm{CRM}$ and customer value, we set out a number of propositions and the possible relationships between the three proposed capabilities and customer value are described; third, the implications of the study are discussed; and finally, the limitations of the proposed model and research perspectives are proposed.

\section{THEORETICAL BACKGROUND}

\subsection{Resources and capabilities in the strategic management literature}

Understanding how firms create and maintain competitive advantage is fundamental in the strategic management field (Zott, 2003). Although many theories have been advanced regarding the sources of competitive advantage, Teece, Pisano and Shuen (1997) have grouped them into three existing paradigms and then describe aspects of a new paradigm that they label 'dynamic capabilities'. These paradigms are a) the competitive forces approach; b) the strategic conflict approach; $c$ ) the resource-based view; and d) the dynamic capabilities approach.

The first two approaches are closely related because they appear to share the view that rents flow from privileged product market positions. The competitive forces approach, developed by Porter (1980), sees the strategic problem in terms of industry structure, entry deterrence and positioning. This approach emphasizes the actions a firm can take to create defensible positions against competitive forces. In the strategic conflict approach, developed by Shapiro (1989), the strategic problem is viewed as a problem of interaction between rivals with certain expectations about how each other will behave.

On the other hand, as we will now discuss, the other two approaches view firm-specific capabilities and resources from inside the firm as the source of competitive advantage (Teece et al., 1997). 
The resource-based view (RBV) was developed by Barney (1991), Peteraf (1993) and Wernerfelt (1984) and expanded by Helfat and Peteraf (2003) and Mahoney and Pandian (1992), among others. The essence of the RBV is its emphasis on resources and capabilities as the origin of competitive advantage.

We must first, therefore, define the terms 'resource' and 'capability'. Resources are 'stocks of available factors owned or controlled by the firm', whereas capabilities refer to 'a firm's capacity to deploy resources, usually in combination, using organizational processes, to effect a desired end' (Amit and Schoemaker, 1993). According to Amit and Schoemaker (1993), capabilities can be thought of abstractly, as 'intermediate goods' generated by the firm to provide enhanced productivity of its resources, as well as strategic flexibility and protection for its final product or service. Makadok (2001) identifies two key features that distinguish a capability from other types of resources. Firstly, a capability is firm-specific, since it is embedded in the firm and its processes, whereas an ordinary resource is not. Because of this embeddedness, ownership of a capability cannot easily be transferred from one firm to another without also transferring ownership of the firm itself, or some subunit of the firm. As Teece et al. (1997) contend, 'that which is distinctive cannot be bought or sold short of buying the whole firm itself, or one or more of its subunits'. If the firm were to be completely dissolved its capabilities would also disappear, but its resources might survive in the hands of a new owner. Secondly, the primary purpose of a capability is to enhance the productivity of the firm's other resources.

The RBV regards the firm as a bundle of resources and capabilities, and assumes that these resources and capabilities are heterogeneously distributed across firms and that this heterogeneity persists over time (Ambrosini and Bowman, 2009; Amit and Schoemaker, 1993; Barney, 1991; Daniel and Wilson, 2003; Mahoney and Pandian, 1992; McKelvie and Davidsson, 2009; Penrose, 1959; Wang and Ahmed, 2007; Wernerfelt, 1984). Based on this assumption, academics suggest that when firms have resources and capabilities which are valuable, rare, inimitable and non-substitutable (VRIN), they can use them to implement value creation strategies that can provide a sustainable competitive advantage (Barney, 1991; Conner and Prahalad, 1996; Nelson, 1991; Peteraf, 1993; Peteraf and Barney, 2003; Prahalad and Hamel, 1990; Wernerfelt, 1984, 1995).

During the 1990s, the highly dynamic business environment challenged the original assumptions of the RBV, which are static and do not take account of market dynamism (Eisenhardt and Martin, 2000; Priem and Butler, 2001a, 2001b). Consequently, Teece et al. (1997) posited the dynamic capabilities approach to address that gap. Although they had previously attempted to introduce the concept of dynamic capabilities (Teece and Pisano, 1994), it was their 1997 article that attracted considerable attention to the new concept within the management literature (Barreto, 2010). As a result, dynamic capabilities are now considered to be an extension of the RBV (Ambrosini and Bowman, 2009; Ambrosini, Bowman and Collier, 2009; Barreto, 2010; Bowman and Ambrosini, 2003; Daniel and Wilson, 2003; Easterby-Smith and Prieto, 2008; Macher and Mowery, 2009). Dynamic capabilities have added value to the RBV arguments as they transform what is essentially a static view into one that encompasses competitive advantage in a dynamic context (Ambrosini et al., 2009; 
Barney, 2001a, 2001b). Dynamic capabilities focus on the firm's ability to face rapidly changing environments, in order to create and renew resources, and change the resources mix (Ambrosini and Bowman, 2009; Bowman and Ambrosini, 2003; Teece et al., 1997).

Our work is based on this last approach. Firms are aware of the customer's demand for superior value and they need to understand how to combine their existing capabilities to enable them to offer this superior value. As we have mentioned previously, the three organizational capabilities most cited in the existing literature as the ones with a major influence in customer value are MO, KM and CRM (Barroso and Martín, 1999; McNaughton, Osborne, Morgan and Kutwaroo, 2001; Rezgui, 2007; Slater and Narver 1994b; Vorakulpipat and Rezgui, 2008; Wang et al., 2004). Those three organizational capabilities view the customer as its key component and try to maximize the value created for them.

\subsection{Market orientation}

Market-oriented firms aim to understand both expressed and latent customer needs, and to develop superior solutions to those needs (Day, 1994; Kohli and Jaworski, 1990; Slater and Narver, 1995). Jaworski and Kohli (1996) point out that reacting to customers' expressed needs is usually insufficient for the creation of competitive advantage. The opportunity to build strong customer loyalty arises when firms have the ability to understand and satisfy customers' latent needs (Slater and Narver, 1999). The greater the $\mathrm{MO}$ of the firm, the greater the proportion of its activities that are oriented to understanding latent needs (Slater and Narver, 1999).

According to Slater and Narver (1995), MO is 'the culture that a) places the highest priority on the profitable creation and maintenance of superior customer value while considering the interests of other key stakeholders; and b) provides norms for behavior regarding the organizational development of and responsiveness to market information'.

It is imperative for firms in a turbulent market to be highly market-oriented. In such conditions, managers must undertake market-oriented activities while at the same time maintaining the flexibility to shift resources and adapt to potential market needs (Pulendran, Speed and Widing, 2000).

Having reviewed some of the numerous definitions of $\mathrm{MO}$ that have been proposed (Day, 1994; Deng and Dart, 1994; Deshpandé and Farley, 1998; Deshpandé, Farley and Webster, 1993; Kaur and Gupta, 2010; Kohli and Jaworski, 1990; Lado, MaydeuOlivares and Rivera, 1998; Narver and Slater, 1990; Narver, Slater and Tietje, 1998; Ruekert, 1992; Shapiro, 1988; Slater and Narver, 1994b; Slater and Narver, 1995; Slater and Narver, 2000; Woodruff, 1997; among others), we define market orientation as 'the generation of appropriate market information pertaining to customers' current and future needs, and the relative abilities of competitive entities to satisfy these needs; the integration and dissemination of such information across departments; and the coordinated design and execution of the firm's strategic response to market opportunities'. 


\subsection{Knowledge management}

The business world's entry into the knowledge era has spawned several new terms that did not exist a few decades ago (Serenko and Bontis, 2004). Obviously, the terms 'knowledge' and 'management' are not new. However, their combination (KM) is fairly recent (Alvesson and Kärreman, 2001) and can be traced back to the emergence of communications technologies (e.g. the Internet, intranets, e-mail) that provide access to computerized networks and enable real-time interaction, regardless of physical distance (Hansen, Nohria and Tierney, 1999; Alvesson and Kärreman, 2001). The popularity of $\mathrm{KM}$ has grown dramatically among both academics and practitioners (Serenko and Bontis, 2004). Just as knowledge is considered as the most important strategic resource, KM is considered to be critical to a firm's success (van den Hooff and Huysman, 2009).

Given the importance of firms' intangible assets, ways must be found of managing them (Spender, 2006). Practitioners see KM as the result of competitive pressures and the need to manage firms' intangible assets more efficiently (Spender and Scherer, 2007).

The recognition of knowledge as a key resource for firms in the current business environment confirms the need for processes that facilitate individual and collective knowledge creation, transfer and leverage (Becerra-Fernandez and Sabherwal, 2001; Drucker, 1993; Ipe, 2003; Nonaka and Takeuchi, 1995). Every firm should understand the importance of knowledge and of teaching knowledge skills to their employees and every employee should be encouraged to create, share, search out and use knowledge in their daily routines (Davenport and Prusak, 1998).

Following a review of some of the numerous definitions of $\mathrm{KM}$ that have been proposed (Alavi and Leidner, 2001; Armbrecht et al., 2001; Bhatt, 2001; Chou, Chang, Cheng and Tsai, 2007; Gold, 2001; Lin, 2007; McDermott, 1999; Neef, 1999; PalaciosMarqués and Garrigós-Simón, 2005; Pan and Scarbrough, 1999; Probst, Raub and Romhardt, 2000; Quintas, Lefrere and Jones, 1997; Ruggles, 1998; Sabherwal and Becerra-Fernandez, 2003; Swan, Newell, Scarbrough and Hislop, 1999; Tirpak, 2005; among others), we define knowledge management as 'the integration of people, technologies, processes and strategies within the firm to create, use and share knowledge'.

\subsection{Customer relationship management}

As Barroso and Martín (1999) note, the relationship concept is an old idea that has always been present in economic markets; nevertheless, its current impetus is due to the importance of the firm retaining its customers. Reichheld and Sasser (1990) demonstrate, in several sectors, the drop in profits that firms experience when the rate of customer retention and loyalty decreases. Increased competition in most sectors and firms' almost exclusive concern for attracting new customers explain these results.

In current conditions, customers are the scarcest and therefore the most valued component of the system. Therefore customer attraction, and importantly, retention, is one of the key factors of business success (Barroso and Martín, 1999). Several 
examples of customer importance can be found in Penrose's (1960) study, which suggests that established customers play a decisive role in generating the idea of moving into new products or services areas, and that the ability to accommodate these requirements leads to the formation and assimilation of previously unexploited resources and capabilities.

Zander and Zander (2005) claim that, for strategy and growth purposes, firms are not necessarily locked into internally controlled resources and capabilities, but may draw on customers as sources of new ideas and problem-solving capabilities, and flexibility in assimilating new resources and capabilities.

After a review of some of the definitions proposed by various authors (Barroso and Martín, 1999; Berry, 1983; Gummeson, 1987; among others), our definition of customer relationship management is 'the firm's activities that are oriented towards creating and maintaining long-term relationships with their customers to obtain their loyalty and satisfaction'.

\section{Insert Table 1}

\subsection{Customer value}

Being able to understand what customers value within a particular offering, creating value for them and then managing it over time have long been recognized as essential elements of firms' business strategy (Drucker, 1985; Porter, 1985, 1998; Slater and Narver, 1998). Determining what customers want in a product or service also helps a firm to formulate its value proposition. Porter (1985) notes that a firm's competitive advantage stems from its ability to create value for its customers that exceeds the firm's cost of creating it (DeSarbo, Jedidi and Sinha, 2001).

'Customer value' emerged in the 1990s as a topic of growing interest for firms; for both academics and practitioners. This concept is considered to be one of a firm's most significant success factors (Gale, 1994; Parasuraman, 1997; Woodruff, 1997; Zeithaml, 1988; Zeithaml, Berry and Parasuraman, 1996) and has been identified as an important source of competitive advantage (Mizik and Jacobson, 2003; Spiteri and Dion, 2004; Woodruff, 1997). Customer value is also seen as the basis of marketing activities (Holbrook, 1996) and is regarded as a critical strategic tool for attracting and retaining customers (Lee and Overby, 2004; Sánchez and Iniesta, 2006; Wang et al., 2004) and as an indicator of repurchase intentions (Parasuraman and Grewal, 2000).

Over the last few decades, firms have found themselves in a new and complex competitive environment, in which customers are increasingly demanding the creation of customer value (Sánchez et al., 2009). A growing number of firms regard customer value as a key factor when looking for new ways to achieve and retain competitive advantage (Woodruff, 1997; Woodruff and Gardial, 1996). This has led to increased interest in the creation and provision of superior customer value (Smith and Colgate, 2007; Wang et al., 2004), by partially replacing more limited concepts such as quality (Cronin, Brady and Hult, 2000) or satisfaction (Sweeney, Soutar and Johnson, 1999; Woodruff, 1997), as has been discussed previously in the literature. 


\section{CONCEPTUAL MODEL}

\subsection{Market orientation and customer value}

Customer orientation is a central ingredient of a customer value-based proposition. According to Han, Kim and Srivastava (1998), customer orientation gives the highest priority to continuously finding ways to provide superior customer value. Narver and Slater (1990) combine customer orientation with competitor orientation and interfunctional coordination in MO (McNaughton et al., 2001). MO influences investment in market-based assets that may be deployed to create customer value (McNaughton et al., 2001).

To create superior customer value, therefore, a firm should be customer-oriented, competitor-oriented and inter-functional coordinated; in other words, it should be market-oriented (Narver and Slater, 1990). Several authors believe that MO is the most effective and efficient culture for creating the behaviors that are required for the creation of superior customer value and, therefore, superior business performance (Aaker, 1988; Kohli and Jaworski, 1990; Kotler, 1984; Kotler and Andreasen, 1987; Shapiro, 1988; Webster, 1988). In addition, Barroso and Martín (1999) state that the culture and behaviors that MO promotes form a solid basis for driving the firm's capabilities that are necessary for creating superior value.

The main element of $\mathrm{MO}$ is the firm's total commitment to the continuous creation of superior customer value (Narver and Slater, 1998). Market-oriented firms are committed to understanding both the expressed and latent needs of their customers, and the capabilities and plans of their competitors, through the processes of acquiring and evaluating market information in a systematic and anticipatory manner (Slater and Narver, 1998). MO facilitates the collection and use of market information, and focuses on the coordination of resources to deliver superior customer value (McNaughton et al., 2001; Slater and Narver, 1994a, 1995). A common argument in the MO literature is that market-oriented firms are in a better position to satisfy their customers (Narver and Slater, 1990). Therefore, using these arguments, we propose that in MO the focus of competitive advantage is the creation and delivery of superior customer value.

Proposition 1a: MO will have a positive relationship with customer value.

\subsection{Knowledge management and customer value}

Firms increasingly see their intellectual assets as strategic resources that can be harnessed and managed effectively to achieve competitive advantage and to survive (Qureshi, Briggs and Hlupic, 2006). In these new economies, information and knowledge are seen as the principal drivers for the creation of value and competitive advantage (Prahalad and Hamel, 1990). Firms obtain information about the customers' needs and they convert that information into knowledge (Alavi and Leidner, 2001; Bhatt, 2001; Davenport and Prusak, 1998; Grover and Davenport, 2001; Nonaka, 1994; Nonaka and Takeuchi, 1995). Indeed, knowledge is perceived as meaningful information. 
There has been considerable discussion in the recent literature of the relationship between KM and customer value (Despres and Chauvel, 1999; Gebert, Geib, Kolbe and Brenner, 2003; Rezgui, 2007). Moreover, Despres and Chauvel (1999) suggest that knowledge can be described as a source of value creation and Gebert et al. (2003) suggest, in terms of organizational processes, that KM processes have inherent value creation capabilities (Vorakulpipat and Rezgui, 2008).

In this context, KM is perceived as a framework for designing a firm's goals, structures and processes so that the firm can use its knowledge to learn and create value for its customers (Vorakulpipat and Rezgui, 2008). Taking the previous arguments as our starting point, we state that one of the objectives of $\mathrm{KM}$ is value creation. A firm that manages its knowledge does so with the aim of increasing the value created for its customers.

Proposition 1b: KM will be positively related to customer value.

\subsection{Customer relationship management and customer value}

From the point of view of relationship marketing, firms should be concerned with the development and maintenance of continuous relationships with their customers, always assuming that these relationships provide value for all the actors involved. If this is not the case, the relationships will break down. Value is therefore viewed as an essential component of CRM, and firms' capacity to deliver superior customer value has been the differentiating factor since the 1990s, as it is seen as the key to achieving and maintaining a sustainable competitive advantage (Barroso and Martín, 1999).

As we have seen, firms desire to create and maintain long-term relationships with customers in order to deliver superior customer value. According to Barroso and Martín (1999), CRM is about creating and maintaining long-term relationships with customers so that, over course of these relationships, a continuous improvement in customer value delivery will evolve.

Proposition 1c: CRM will have a positive relationship with customer value.

\subsection{Interaction between organizational capabilities}

Firstly, we propose that a relationship exists between $\mathrm{MO}$ and $\mathrm{KM}$. This relationship appears to be possible in two directions.

On the one hand, we can state that $\mathrm{MO}$ positively influences $\mathrm{KM}$, that is to say, a firm is able to create superior value if it is market-oriented and can subsequently manage its knowledge. When a firm is market-oriented, the firm obtains customer information, disseminates it and responds to it. If we link this capacity to $\mathrm{KM}$, the result is that external information could be stored, the systems for transferring this information would improve and it could then be integrated into the firm.

On the other hand, it is possible to posit the opposite relationship; which is that KM positively influences $\mathrm{MO}$, which allows superior customer value to be created. In this case, firms first prepare themselves for managing the information, by promoting the appropriate culture among its employees and incorporating the technology and 
processes that allow them to manage the information. Once firms have the appropriate $\mathrm{KM}$ infrastructure in place, they are oriented to the market, are able to capture and disseminate the information about their customers' needs and are able to respond to it.

As mentioned above, the direction of the relationship between these two variables does not seem clear and an empirical study would therefore be required to test it. Nevertheless, having discussed both possibilities, it seems more appropriate to state that firms first look within themselves to make sure they have the necessary KM infrastructure and then they look outside, to obtain the necessary information about their customers. Once this information is being managed inside the firm, customer value is created.

We can justify our choice of relationship by referring to the relationship between organizational learning and MO. According to Huber (1991), we define organizational learning as the development of new knowledge and ideas with the potential to influence the behavior. Slater and Narver (1995) state that without organizational learning, MO has no positive effects on business performance. Consequently, it would appear that $\mathrm{MO}$ alone is insufficient for firms to learn. Success does not only depend on the actions of acquisition, dissemination and reaction to market information and therefore it seems that organizational learning helps $\mathrm{MO}$, and we suggest that organizational learning is the basis of $\mathrm{KM}$. These arguments lead us to propose the following relationship between $\mathrm{MO}$ and $\mathrm{KM}$.

Proposition 2a: KM will influence MO, which encourages the creation of superior customer value.

The next relationship that we propose is that which exists between KM and CRM. Although current opinion generally regards these concepts as separate areas of research, Gebert et al. (2003) show that the integration of CRM and KM at the process level is beneficial to both management approaches. On the one hand, customeroriented $\mathrm{KM}$ focuses on the type of knowledge that is most valuable to the firm customer knowledge- whereas on the other hand, knowledge-oriented CRM can use a conceptual framework for the cost-effective management of the knowledge required for high quality relationships (Gebert et al., 2003).

The direction of this relationship seems clearer than the previous one. A firm relies on its KM infrastructure to create and maintain long-term relationships with its customers. If a firm's people, technology and processes are oriented towards managing knowledge, it is more likely to make appropriate use of the information regarding its customers. This will give firms a broad understanding of their customers, which allows them to translate this information into key processes through which to create superior customer value. By managing their customer relationships, firms are managing knowledge. In order to build good relationships with customers, each one must be served in their preferred way and therefore 'customer knowledge' must be managed (Davenport, Harris and Kohli, 2001). In fact, KM is a critical factor for the success of CRM (Gebert et al., 2003; Liyun et al., 2008).

Whereas KM systems manage firms' knowledge through the processes of creating, structuring, disseminating and applying knowledge to enhance its performance and to 
create value (Alavi and Leidner, 2001; Davenport and Prusak, 1998; Offsey, 1997), CRM focuses on transactional exchanges to manage customers' interactions. Integrating KM skills with CRM activities will help firms to manage customers' needs based on what is known about them, rather than on the mass generalization of customers' characteristics (Bose and Sugumaran, 2003). CRM should be able not only to collect relevant information and enable it to be available at the right moment, but also to provide tools for analyzing and sharing the information in a meaningful way, allowing managers to act rapidly. Therefore, according to Bose and Sugumaran (2003), a knowledge-oriented CRM would provide exactly the types of capabilities required to make CRM effective in the management of lasting relationships with valuable customers.

In this case, it is also interesting to emphasize the role of $\mathrm{KM}$ in the transfer of 'best practices'. As part of KM, a firm records which practice it used for each of its customers and whether the results were favorable or not. This information storage allows firms to identify their 'best practices' in relation to CRM and to apply them throughout the firm to encourage the creation of new relationships or the maintenance of the existing ones.

Proposition 2b: KM will influence CRM, encouraging the creation of superior customer value.

We suggest that another relationship exists between $\mathrm{MO}$ and CRM. In this case, we propose that MO influences CRM (Javalgi, Martin and Young, 2006). It is clear that there are similarities between these two capabilities (both are oriented towards the satisfaction of customers' desires and preferences; both involve the whole firm, not just the marketing department; and both take a long-term view). Using the work put forward by Barroso and Martín (1999), we propose that CRM constitutes a way of being market-oriented, with the emphasis on customer orientation. Firms attempt to establish and exploit long-term relationships in order to build customer loyalty and to make a positive impact on their economic performance. This statement explains our proposed relationship between $\mathrm{MO}$ and $\mathrm{CRM}$.

Proposition 2c: MO will influence CRM, encouraging the creation of superior customer value.

Finally, we propose a relationship that links the interaction between the three capabilities and customer value.

Proposition 3: Interaction between MO, KM and CRM (according to our previous propositions) will be positively related to customer value.

\section{Insert Table 2}

\subsection{Research model}

All of the proposed relationships are shown in Figure 1. The research model states that the three proposed organizational capabilities (MO, KM and CRM) influence a firm's capacity to create superior customer value.

\section{Insert Figure 1}


The principal driving force behind the proposed relationships is knowledge. Both KM and $\mathrm{MO}$ are sources of knowledge. Flows of knowledge between the organizational capabilities (MO, KM and $\mathrm{CRM}$ ) facilitate the changes that are required within firms to create superior customer value. Therefore, managing this interaction between the organizational capabilities is a source of competitive advantage -in this case customer value creation- because the resource that flows between them is knowledge.

It should also be emphasized that to achieve competitive advantage it is not knowledge itself that is important, but rather the firms' capacity to apply this knowledge effectively in order to create new knowledge (Grant, 1996b), as shown in our model. Knowledge flows from one capability to another, through the reconfiguration of organizational capabilities, leading to new knowledge that enables the firm to create superior customer value. This is where dynamic capabilities come into play.

As shown in the previous figure, we propose that the interaction between the three organizational capabilities constitutes a dynamic capability. Firms are aware of their customers' demand for superior value and they need to know how to combine their existing capabilities in order to offer this superior value. It is clear therefore that we should turn to dynamic capabilities to explain how the interaction between the three capabilities is linked to superior customer value.

\section{IMPLICATIONS FOR RESEARCH AND MANAGEMENT}

Our research model studies the interaction between $\mathrm{MO}, \mathrm{KM}$ and $\mathrm{CRM}$, and its influence on customer value. We propose that the interaction between these three capabilities constitutes a dynamic capability of the firm, and has a direct influence on the increase in customer value. This model contributes to the existing literature in several ways.

The first key contribution of this work is its inclusion of the concept of dynamic capabilities; in this way, we prove that firms are able to compete not only due to their ability to exploit their existing resources and capabilities, but also thanks to their ability to renovate and develop their organizational capabilities (Teece et al., 1997). Therefore, we argue that in order to maintain competitiveness it is not enough for firms to be in possession of valuable resources and capabilities; firms also require dynamic capabilities to develop and renovate their organizational resources and capabilities (Teece et al., 1997).

Secondly, the analysis of the interaction between a firm's capabilities ( $\mathrm{MO}, \mathrm{KM}$ and CRM) allows us to see what happens inside the proposed 'black box' for increasing customer value. This interaction forms our proposed dynamic capability. To confirm that the interaction between the three proposed capabilities really is a dynamic capability, it is necessary to test whether the characteristics of dynamic capabilities are fulfilled as expected in the specific organizational capabilities that we are studying.

Thirdly, we believe that this topic is of interest because of its novelty, since it is rarely mentioned in the literature, and also because of its relevance, given that these variables are frequently investigated nowadays. 
The findings of this work also could improve current firms' management by enabling these firms to achieve their objective of creating superior customer value.

First of all, we try to show managers how they can create superior customer value by analyzing what happens inside the proposed 'black box'. Our study is based on the assumption that firms possess the capabilities of MO, KM and CRM, each of which allows the firm to create value. If each one contributes individually to a firm's success, will their combination enhance this positive effect? We propose that the interaction between these three capabilities will allow managers to create superior customer value. Thus, managers should realize that although each organizational capability is important individually, the three should be related to create superior value.

Second, we aim to provide managers with a guide to improving customer value. These firms may possess the capabilities required for improving their competitive advantage but are not aware of it or do not know how to go about achieving the desired result.

Finally, for academics and practitioners alike, this paper presents the possibility for increasing the value created for customers, which is a key factor for the growing number of firms seeking new ways to achieve and maintain competitive advantage.

\section{CONCLUSIONS}

In recent years, customers have become the center of attention and in one way or another every firm seeks to satisfy them. Some firms are market-oriented in order to create superior customer value through the culture and behaviors that this orientation promotes. Other firms prefer to manage their knowledge, while others focus on creating and maintaining long-term relationships with their customers.

In this paper, we propose a model which combines these three organizational capabilities. The primary contribution of this work is the inclusion of the concept of dynamic capabilities. This concept suggests to us that firms can compete not only because of their ability to exploit their existing resources and capabilities, but because they have the ability to renovate and develop their organizational capabilities. Therefore, value creation should not be attributed solely to the individual existence of the three proposed organizational capabilities, but also to the capacity to combine them. Understanding how to combine those capabilities is fundamental to a firm's success.

Our research model focus on the three capabilities that we consider the most important for increasing the value created for the customer. Obviously, it could be possible to find other capabilities that could be included in our model.

In this paper, our purpose is to offer a theoretical explanation of the proposed model. Future research needs to test empirically whether our propositions are supported or not supported.

The next step to progress about this research stream, building on the existing literature on dynamic capabilities, is to find evidence that demonstrates that the interaction between the three proposed capabilities really does constitute a dynamic capability. 6 . REFERENCES 
Aaker, D. A. (1988), Strategic Market Management, John Wiley \& Sons, New York.

Alavi, M. and Leidner, D. E. (2001), "Review: Knowledge Management and Knowledge Management Systems: Conceptual Foundations and Research Issues", MIS Quarterly, Vol. 25 No. 1, pp. 107-136.

Alvesson, M. and Kärreman, D. (2001), "Odd Couple: Making Sense of the Curious Concept of Knowledge Management", Journal of Management Studies, Vol. 38 No. 7, pp. 995-1018.

Ambrosini, V. and Bowman, C. (2009), "What Are Dynamic Capabilities and Are They a Useful Construct in Strategic Management?", International Journal of Management Reviews, Vol. 11 No. 1, pp. 29-49.

Ambrosini, V., Bowman, C. and Collier, N. (2009), "Dynamic Capabilities: An Exploration of How Firms Renew Their Resource Base", British Journal of Management, Vol. 20, pp. S9-S24.

Amit, R. and Schoemaker, P. J. H. (1993), "Strategic Assets and Organizational Rent", Strategic Management Journal, Vol. 14 No. 1, pp. 33-46.

Armbrecht, F. M. R., Chapas, R. B., Chappelow, C. C., Farris, G. F., Friga, P. N., Hartz, C. A., Mcllvaine, M. E., Postle, S. R. and Whitwell, G. E. (2001), "Knowledge Management in Research and Development", Research Technology Management, Vol. 44 No. 4, pp. 28-48.

Barney, J. B. (1991), "Firm Resources and Sustained Competitive Advantage", Journal of Management, Vol. 17 No. 1, pp. 99-120.

Barney, J. B. (2001a), "Is the Resource-Based "View" a Useful Perspective for Strategic Management Research? Yes", Academy of Management Review, Vol. 26 No. 1 , pp. 41-56.

Barney, J. B. (2001b), "Resource-Based Theories of Competitive Advantage: A TenYear Retrospective on the Resource-Based View", Journal of Management, Vol. 27 No. 6, pp. 643-650.

Barreto, I. (2010), "Dynamic Capabilities: A Review of Past Research and an Agenda for the Future", Journal of Management, Vol. 36 No. 1, pp. 256-280.

Barroso, C. and Martín, E. (1999), Marketing Relacional, ESIC Editorial, Madrid.

Becerra-Fernandez, I. and Sabherwal, R. (2001), "Organizational Knowledge Management: A Contingency Perspective", Journal of Management Information Systems, Vol. 18 No. 1, pp. 23-55.

Berry, L. L. (1983), "Relationships Marketing", in Berry, L. L., Shostack, G. L. and Upsay, G. (Eds.), Emerging Perspectives on Services Marketing, American Marketing Association, Chicago, pp. 25-28.

Bhatt, G. D. (2001), "Knowledge Management in Organizations: Examining the Interaction between Technologies, Techniques, and People", Journal of Knowledge Management, Vol. 5 No. 1, pp. 68-75.

Bose, R. and Sugumaran, V. (2003), "Application of Knowledge Management Technology in Customer Relationship Management", Knowledge and Process Management, Vol. 10 No. 1, pp. 3-17.

Bowman, C. and Ambrosini, V. (2003), "How the Resource-Based and the Dynamic Capability Views of the Firm Inform Corporate-Level Strategy", British Journal of Management, Vol. 14 No. 4, pp. 289-303.

Conner, K. R. and Prahalad, C. K. (1996), "A Resource-Based Theory of the Firm: Knowledge Versus Opportunism", Organization Science, Vol. 7 No. 5, pp. 477501.

Cronin, J. J., Brady, M. K. and Hult, G. T. M. (2000), "Assessing the Effects of Quality, Value, and Customer Satisfaction on Consumer Behavioral Intentions in Service Environments", Journal of Retailing, Vol. 76 No. 2, pp. 193-218.

Chou, T.-C., Chang, P.-L., Cheng, Y.-P. and Tsai, C.-T. (2007), "A Path Model Linking Organizational Knowledge Attributes, Information Processing Capabilities, and Perceived Usability", Information \& Management, Vol. 44 No. 4, pp. 408-417. 
Daniel, E. and Wilson, H. N. (2003), "The Role of Dynamic Capabilities in E-Business Transformation", European Journal of Information Systems, Vol. 12 No. 4, pp. 282-296.

Davenport, T. H., Harris, J. G. and Kohli, A. K. (2001), "How Do They Know Their Customers So Well?", MIT Sloan Management Review, Vol. 42 No. 2, pp. 6373.

Davenport, T. H. and Prusak, L. (1998), Working Knowledge, Harvard Business School Press, Boston, MA.

Day, G. S. (1994), "The Capabilities of Market-Driven Organizations", Journal of Marketing, Vol. 58 No. 4, pp. 37-52.

Deng, S. and Dart, J. (1994), "Measuring Market Orientation: A Multi-factor, Multi-item Approach", Journal of Marketing Management, Vol. 10 No. 8, pp. 725-742.

DeSarbo, W. S., Jedidi, K. and Sinha, I. (2001), "Customer Value Analysis in a Heterogeneous Market", Strategic Management Journal, Vol. 22 No. 9, pp. 845857.

Deshpandé, R. and Farley, J. U. (1998), "Measuring Market Orientation: Generalization and Synthesis", Journal of Market Focused Management, Vol. 2 No. 3, pp. 213232.

Deshpandé, R., Farley, J. U. and Webster Jr, F. E. (1993), "Corporate Culture Customer Orientation, and Innovativeness in Japanese Firms: A Quadrad Analysis", Journal of Marketing, Vol. 57 No. 1, pp. 23-37.

Despres, C. and Chauvel, D. (1999), "Knowledge Management(s)", Journal of Knowledge Management, Vol. 3 No. 2, pp. 110-123.

Drucker, P. F. (1985), Innovation and Entrepreneurship, Harper and Row, New York.

Drucker, P. F. (1993), Post-Capitalist Society, Harper Collins, New York, NY.

Easterby-Smith, M. and Prieto, I. (2008), "Dynamic Capabilities and Knowledge Management: An Integrative Role for Learning?", British Journal of Management, Vol. 19 No. 3, pp. 235-249.

Eisenhardt, K. M. and Martin, J. A. (2000), "Dynamic Capabilities: What Are They?", Strategic Management Journal, Vol. 21 No. 10/11, pp. 1105-1121.

Gale, B. T. (1994), Managing Customer Value. Creating Quality \& Service That Customers Can See, The Free Press, New York.

Gebert, H., Geib, M., Kolbe, L. and Brenner, W. (2003), "Knowledge-Enabled Customer Relationship Management: Integrating Customer Relationship Management and Knowledge Management Concepts[1]", Journal of Knowledge Management, Vol. 7 No. 5, pp. 107-123.

Gold, A. H. (2001). Towards a Theory of Organizational Knowledge Management Capabilities. Unpublished Ph.D., University of North Carolina, Chapel Hill.

Grant, R. M. (1996a), "Toward a Knowledge-Based Theory of the Firm", Strategic Management Journal, Vol. 17 Winter Special Issue, pp. 109-122.

Grant, R. M. (1996b), "Prospering in Dynamically-Competitive Environments: Organizational Capability as Knowledge Integration", Organization Science, Vol. 7 No. 4, pp. 375-387.

Grover, V and Davenport, T. H. (2001), "General Perspectives on Knowledge Management: Fostering a Research Agenda", Journal of Management Information Systems, Vol. 18 No. 1, pp. 5-21.

Gummesson, E. (1987), "The New Marketing - Developing Long Term Interactive Relationships", Long Range Planning, Vol. 20 No. 4, pp. 10-20.

Han, J. K., Kim, N. and Srivastava, R. K. (1998), "Market Orientation and Organizational Performance: Is Innovation a Missing Link?", Journal of Marketing, Vol. 62 No. 4, pp. 30-45.

Hansen, M. T., Nohria, N. and Tierney, T. (1999), "What's Your Strategy for Managing Knowledge?", Harvard Business Review, Vol. 77 No. 2, pp. 106-116. 
Helfat, C. E. and Peteraf, M. A. (2003), "The Dynamic Resource-Based View: Capability Lifecycles", Strategic Management Journal, Vol. 24 No. 10, pp. 9971010.

Holbrook, M. B. (1996), "Customer Value - a Framework for Analysis and Research", Advances in Consumer Research, Vol. 23 No. 1, pp. 138-142.

Huber, G. P. (1991), "Organizational Learning: The Contributing Processes and Literatures", Organization Science, Vol. 2 No. 1, pp. 88-115.

Ipe, M. (2003), "Knowledge Sharing on Organizations: A Conceptual Framework", Human Resource Development Review, Vol. 2 No. 4, pp. 337-359.

Javalgi, R. G., Martin, C. L. and Young, R. B. (2006), "Marketing Research, Market Orientation and Customer Relationship Management: A Framework and Implications for Service Providers", Journal of Services Marketing, Vol. 20 No. 1, pp. 12-23.

Jaworski, B. J. and Kohli, A. K. (1996), "Market Orientation: Review, Refinement and Roadmap", Journal of Market Focused Management, Vol. 1 No. 2, pp. 119-135.

Kaur, G. and Gupta, M. C. (2010), "A Perusal of Extant Literature on Market Orientation - Concern for Its Implementation", Marketing Review, Vol. 10 No. 1, pp. 87-105.

Kohli, A. K. and Jaworski, B. J. (1990), "Market Orientation: The Construct, Research Propositions, and Managerial Implications", Journal of Marketing, Vol. 54 No. 2, pp. 1-18.

Kotler, P. (1984), Marketing Management; Analysis, Planning and Control, PrenticeHall, Englewood Cliffs, NJ.

Kotler, P. and Andreasen, A. R. (1987), Strategic Marketing for Nonprofit Organizations, Prentice-Hall, Englewood Cliffs, NJ.

Lado, N., Maydeu-Olivares, A. and Rivera, J. (1998), "Measuring Market Orientation in Several Populations", European Journal of Marketing, Vol. 32 No. 1/2, pp. 2339.

Lee, E.-J. and Overby, J. W. (2004), "Creating Value for Online Shoppers: Implications for Satisfaction and Loyalty", Journal of Consumer Satisfaction, Dissatisfaction and Complaining Behavior, Vol. 17, pp. 54.

Lin, H. (2007), "A Stage Model of Knowledge Management: An Empirical Investigation of Process and Effectiveness", Journal of Information Science, Vol. 33 No. 6, pp. 643-659.

Liyun, Q., Keyi, W., Xiaoshu, W. and Fangfang, Z. (2008), "Research on the Relationship among Market Orientation, Customer Relationship Management, Customer Knowledge Management and Business Performance", Management Science and Engineering, Vol. 2 No. 1, pp. 31-37.

Macher, J. T. and Mowery, D. C. (2009), "Measuring Dynamic Capabilities: Practices and Performance in Semiconductor Manufacturing", British Journal of Management, Vol. 20, pp. S41-S62.

Mahoney, J. T. and Pandian, J. R. (1992), "The Resource-Based View within the Conversation of Strategic Management", Strategic Management Journal, Vol. 13 No. 5, pp. 363-380.

Makadok, R. (2001), "Toward a Synthesis of the Resource-Based and DynamicCapability Views of Rent Creation", Strategic Management Journal, Vol. 22 No. 5, pp. 387-401.

McDermott, R. (1999), "Why Information Technology Inspired but Cannot Deliver Knowledge Management", California Management Review, Vol. 41 No. 4, pp. 103-117.

McKelvie, A. and Davidsson, P. (2009), "From Resource Base to Dynamic Capabilities: An Investigation of New Firms", British Journal of Management, Vol. 20, pp. S63-S80. 
McNaughton, R. B., Osborne, P., Morgan, R. E. and Kutwaroo, G. (2001), "Market Orientation and Firm Value", Journal of Marketing Management, Vol. 17 No. 5/6, pp. 521-542.

Mizik, N. and Jacobson, R. (2003), "Trading Off between Value Creation and Value Appropriation: The Financial Implications of Shifts in Strategic Emphasis", Journal of Marketing, Vol. 67 No. 1, pp. 63-76.

Morrow, J. L., Sirmon, D. G., Hitt, M. A. and Holcomb, T. R. (2007), "Creating Value in the Face of Declining Performance: Firm Strategies and Organizational Recovery", Strategic Management Journal, Vol. 28 No. 3, pp. 271-283.

Narver, J. C. and Slater, S. F. (1990), "The Effect of a Market Orientation on Business Profitability", Journal of Marketing, Vol. 54 No. 4, pp. 20-35.

Narver, J. C. and Slater, S. F. (1998), "Additional Thoughts on the Measurement of Market Orientation: A Comment on Deshpande and Farley", Journal of Market Focused Management, Vol. 2 No. 3, pp. 233-236.

Narver, J. C., Slater, S. F. and Tietje, B. (1998), "Creating a Market Orientation", Journal of Market Focused Management, Vol. 2 No. 3, pp. 241-256.

Neef, D. (1999), "Making the Case for Knowledge Management: The Bigger Picture", Management Decision, Vol. 37 No. 1, pp. 72-78.

Nelson, R. R. (1991), "Why Do Firms Differ, and How Does It Matter?", Strategic Management Journal, Vol. 12 No. 8, pp. 61-74.

Nonaka, I. (1994), "A Dynamic Theory of Organizational Knowledge Creation", Organization Science, Vol. 5 No. 1, pp. 14-37.

Nonaka, I. and Takeuchi, H. (1995), The Knowledge-Creating Company: How Japanese Companies Create the Dynamics of Innovation, Oxford University Press, New York, NY.

Offsey, S. (1997), "Knowledge Management: Linking People to Knowledge for Bottom Line Results", Journal of knowledge management, Vol. 1 No. 2, pp. 113-122.

Palacios-Marqués, D. and Garrigós-Simón, F. J. (2005), "A Measurement Scale for Knowledge Management in the Biotechnology and Telecommunications Industries", International Journal of Technology Management, Vol. 31 No. 3/4, pp. 358-374.

Pan, S. L. and Scarbrough, H. (1999), "Knowledge Management in Practice: An Exploratory Case Study", Technology Analysis \& Strategic Management, Vol. 11 No. 3, pp. 359-374.

Parasuraman, A. (1997), "Reflections on Gaining Competitive Advantage through Customer Value", Journal of the Academy of Marketing Science, Vol. 25 No. 2, pp. 154-161.

Parasuraman, A. and Grewal, D. (2000), "Serving Customers and Consumers Effectively in the Twenty-First Century: A Conceptual Framework and Overview", Journal of the Academy of Marketing Science, Vol. 28 No. 1, pp. 916.

Penrose, E. (1959), The Theory of the Growth of the Firm, Basil Blackwell, London.

Penrose, E. (1960), "The Growth of the Firm- a Case Study: The Hercules Powder Company", The Business History Review, Vol. XXXIV No. 1, pp. 1-23.

Peteraf, M. A. (1993), "The Cornerstones of Competitive Advantage: A ResourceBased View", Strategic Management Journal, Vol. 14 No. 3, pp. 179-191.

Peteraf, M. A. and Barney, J. B. (2003), "Unraveling the Resource-Based Tangle", Managerial \& Decision Economics, Vol. 24 No. 4, pp. 309-323.

Porter, M. E. (1980), Competitive Strategy, Free Press, New York.

Porter, M. E. (1985), Competitive Advantage Creating and Sustaining Superior Performance, Free Press, New York.

Porter, M. E. (1998), Competitive Advantage: Creating and Sustaining Superior Performance, Free Press, New York. 
Prahalad, C. K. and Hamel, G. (1990), "The Core Competence of the Corporation", Harvard Business Review, Vol. 68 No. 3, pp. 79-91.

Priem, R. L. and Butler, J. E. (2001a), "Is the Resource-Based "View" a Useful Perspective for Strategic Management Research?", Academy of Management Review, Vol. 26 No. 1, pp. 22-40.

Priem, R. L. and Butler, J. E. (2001b), "Tautology in the Resource-Based View and the Implications of Externally Determined Resource Value: Further Comments", Academy of Management Review, Vol. 26 No. 1, pp. 57-66.

Probst, G., Raub, S. and Romhardt, K. (2000), Managing Knowledge: Building Blocks for Success, John Wiley, Chichester.

Pulendran, S., Speed, R. and Widing, R. E. (2000), "The Antecedents and Consequences of Market Orientation in Australia", Australian Journal of Management, Vol. 25 No. 2, pp. 119-143.

Quintas, P., Lefrere, P. and Jones, G. (1997), "Knowledge Management: A Strategic Agenda", Long Range Planning, Vol. 30 No. 3, pp. 385-391.

Qureshi, S., Briggs, R. O. and Hlupic, V. (2006), "Value Creation from Intellectual Capital: Convergence of Knowledge Management and Collaboration in the Intellectual Bandwidht Model", Group Decision and Negotiation, Vol. 15, pp. 197-220.

Reichheld, F. F. and Sasser Jr, W. E. (1990), "Zero Defections: Quality Comes to Services", Harvard Business Review, Vol. 68 No. 5, pp. 105-111.

Rezgui, Y. (2007), "Knowledge Systems and Value Creation", Industrial Management \& Data Systems, Vol. 107 No. 2, pp. 166-182.

Ruekert, R. W. (1992), "Developing a Market Orientation: An Organizational Strategy Perspective", International Journal of Research in Marketing, Vol. 9 No. 3, pp. 225-245.

Ruggles, R. (1998), "The State of the Notion: Knowledge Management in Practice", California Management Review, Vol. 40 No. 3, pp. 80-89.

Sabherwal, R. and Becerra-Fernandez, I. (2003), "An Empirical Study of the Effect of Knowledge Management Processes at Individual, Group, and Organizational Levels", Decision Sciences, Vol. 34 No. 2, pp. 225-260.

Sánchez, R. and Iniesta, M. A. (2006), "Consumer Perception of Value: Literature Review and a New Conceptual Framework", Journal of Consumer Satisfaction, Dissatisfaction and Complaining Behavior, Vol. 19, pp. 40-48.

Sánchez, R., Iniesta, M. A. and Holbrook, M. B. (2009), "The Conceptualisation and Measurement of Consumer Value in Services", International Journal of Market Research, Vol. 51 No. 1, pp. 93-113.

Serenko, A. and Bontis, N. (2004), "Meta-Review of Knowledge Management and Intellectual Capital Literature: Citation Impact and Research Productivity Rankings", Knowledge and Process Management, Vol. 11 No. 3, pp. 185-198.

Shapiro, B. P. (1988), "What the Hell Is Market Oriented?", Harvard Business Review, Vol. 66 No. 6, pp. 119-125.

Shapiro, C. (1989), "The Theory of Business Strategy", RAND Journal of Economics, Vol. 20 No. 1, pp. $125-137$.

Sirmon, D. G., Hitt, M. A. and Ireland, R. D. (2007), "Managing Firm Resources in Dynamic Environments to Create Value: Looking inside the Black Box", Academy of Management Review, Vol. 32 No. 1, pp. 273-292.

Slater, S. F. and Narver, J. C. (1994a), "Does Competitive Environment Moderate the Market Orientation-Performance Relationship?", Journal of Marketing, Vol. 58 No. 1, pp. 46-55.

Slater, S. F. and Narver, J. C. (1994b), "Market Orientation, Customer Value, and Superior Performance", Business Horizons, Vol. 37 No. 2, pp. 22-28.

Slater, S. F. and Narver, J. C. (1995), "Market Orientation and the Learning Organization", Journal of Marketing, Vol. 59 No. 3, pp. 63-74. 
Slater, S. F. and Narver, J. C. (1998), "Customer-Led and Market-Oriented: Let's Not Confuse the Two", Strategic Management Journal, Vol. 19 No. 10, pp. 10011006.

Slater, S. F. and Narver, J. C. (1999), "Market-Oriented Is More Than Being CustomerLed", Strategic Management Journal, Vol. 20 No. 12, pp. 1165-1168.

Slater, S. F. and Narver, J. C. (2000), "The Positive Effect of a Market Orientation on Business Profitability: A Balanced Replication", Journal of Business Research, Vol. 48 No. 1, pp. 69-73.

Smith, J. B. and Colgate, M. (2007), "Customer Value Creation: A Practical Framework", Journal of Marketing Theory \& Practice, Vol. 15 No. 1, pp. 7-23.

Spender, J. C. (2006), "Getting Value from Knowledge Management", The TQM Magazine, Vol. 18 No. 3, pp. 238-254.

Spender, J. C. and Scherer, A. G. (2007), "The Philosophical Foundations of Knowledge Management: Editors' Introduction", Organization, Vol. 14 No. 1, pp. 5-28.

Spiteri, J. M. and Dion, P. A. (2004), "Customer Value, Overall Satisfaction, End-User Loyalty, and Market Performance in Detail Intensive Industries", Industrial Marketing Management, Vol. 33 No. 8, pp. 675-687.

Swan, J., Newell, S., Scarbrough, H. and Hislop, D. (1999), "Knowledge Management and Innovation: Networks and Networking", Journal of Knowledge Management, Vol. 3 No. 4, pp. 262-275.

Sweeney, J. C., Soutar, G. N. and Johnson, L. W. (1999), "The Role of Perceived Risk in the Quality-Value Relationship: A Study in a Retail Environment", Journal of Retailing, Vol. 75 No. 1, pp. 77-105.

Teece, D. J. and Pisano, G. (1994), "The Dynamic Capabilities of Firms: An Introduction", Industrial \& Corporate Change, Vol. 3 No. 3, pp. 537-556.

Teece, D. J., Pisano, G. and Shuen, A. (1997), "Dynamic Capabilities and Strategic Management", Strategic Management Journal, Vol. 18 No. 7, pp. 509-533.

Tirpak, T. M. (2005), "Five Steps to Effective Knowledge Management", Research Technology Management, Vol. 48 No. 3, pp. 15-16.

van den Hooff, B. and Huysman, M. (2009), "Managing Knowledge Sharing: Emergent and Engineering Approaches", Information \& Management, Vol. 46 No. 1, pp. 18.

Vorakulpipat, C. and Rezgui, Y. (2008), "Value Creation: The Future of Knowledge Management", The Knowledge Engineering Review, Vol. 23 No. 3, pp. 283-294.

Wang, C. L. and Ahmed, P. K. (2007), "Dynamic Capabilities: A Review and Research Agenda", International Journal of Management Reviews, Vol. 9 No. 1, pp. 3151.

Wang, Y., Lo, H. P., Chi, R. and Yang, Y. (2004), "An Integrated Framework for Customer Value and Customer-Relationship-Management Performance: A Customer-Based Perspective from China", Managing Service Quality, Vol. 14 No. 2/3, pp. 169-182.

Webster, F. E. (1988), "The Rediscovery of the Marketing Concept", Business Horizons, Vol. 31 No. 3, pp. 29-39.

Wernerfelt, B. (1984), "A Resource-Based View of the Firm", Strategic Management Journal, Vol. 5 No. 2, pp. 171-180.

Wernerfelt, B. (1995), "The Resource-Based View of the Firm: Ten Years After", Strategic Management Journal, Vol. 16 No. 3, pp. 171-174.

Woodruff, R. B. (1997), "Customer Value: The Next Source for Competitive Advantage", Journal of the Academy of Marketing Science, Vol. 25 No. 2, pp. 139-153.

Woodruff, R. B. and Gardial, S. F. (1996), Know Your Customer: New Approaches to Understanding Customer Value and Satisfaction, Blackwell Business, Cambridge, MA. 
Zander, I. and Zander, U. (2005), "The inside Track: On the Important (but Neglected) Role of Customers in the Resource-Based View of Strategy and Firm Growth", Journal of Management Studies, Vol. 42 No. 8, pp. 1519-1548.

Zeithaml, V. A. (1988), "Consumer Perceptions of Price, Quality, and Value: A MeansEnd Model and Synthesis of Evidence", Journal of Marketing, Vol. 52 No. 3, pp. 2-22.

Zeithaml, V. A., Berry, L. L. and Parasuraman, A. (1996), "The Behavioral Consequences of Service Quality", Journal of Marketing, Vol. 60 No. 2, pp. 3146.

Zott, C. (2003), "Dynamic Capabilities and the Emergence of Intraindustry Differential Firm Performance: Insights from a Simulation Study", Strategic Management Journal, Vol. 24 No. 2, pp. 97-125.

Table 1

Definitions of the three organizational capabilities of the model

\begin{tabular}{|l|l|}
\hline Organizational capability & Definition \\
\hline Market orientation & $\begin{array}{l}\text { 'The generation of appropriate market information pertaining to customers' current and } \\
\text { future needs, and the relative abilities of competitive entities to satisfy these needs; the } \\
\text { integration and dissemination of such information across departments; and the } \\
\text { coordinated design and execution of the firm's strategic response to market } \\
\text { opportunities' }\end{array}$ \\
\hline Knowledge management & $\begin{array}{l}\text { 'Integration of people, technologies, processes and strategy within the firm to create, } \\
\text { use and share knowledge' }\end{array}$ \\
\hline $\begin{array}{l}\text { Customer relationship } \\
\text { management }\end{array}$ & $\begin{array}{l}\text { 'Firm's activities that are oriented towards creating and maintaining long-term } \\
\text { relationships with their customers to obtain their loyalty and satisfaction' }\end{array}$ \\
\hline
\end{tabular}

Source: Own elaboration

Table 2

Propositions list

\begin{tabular}{|l|l}
\hline Proposition 1a & MO will have a positive relationship with customer value
\end{tabular} 


\begin{tabular}{|l|l|}
\hline Proposition 1b & KM will be positively related to customer value \\
\hline Proposition 1c & CRM will have a positive relationship with customer value \\
\hline Proposition 2a & KM will influence MO, which encourages the creation of superior customer value \\
\hline Proposition 2b & KM will influence CRM, encouraging the creation of superior customer value \\
\hline Proposition 2c & MO will influence CRM, encouraging the creation of superior customer value \\
\hline Proposition 3 & $\begin{array}{l}\text { Interaction between MO, KM and CRM (according to our previous propositions) will be positively } \\
\text { related to customer value }\end{array}$ \\
\hline
\end{tabular}

Source: Own elaboration

Figure 1

Research model

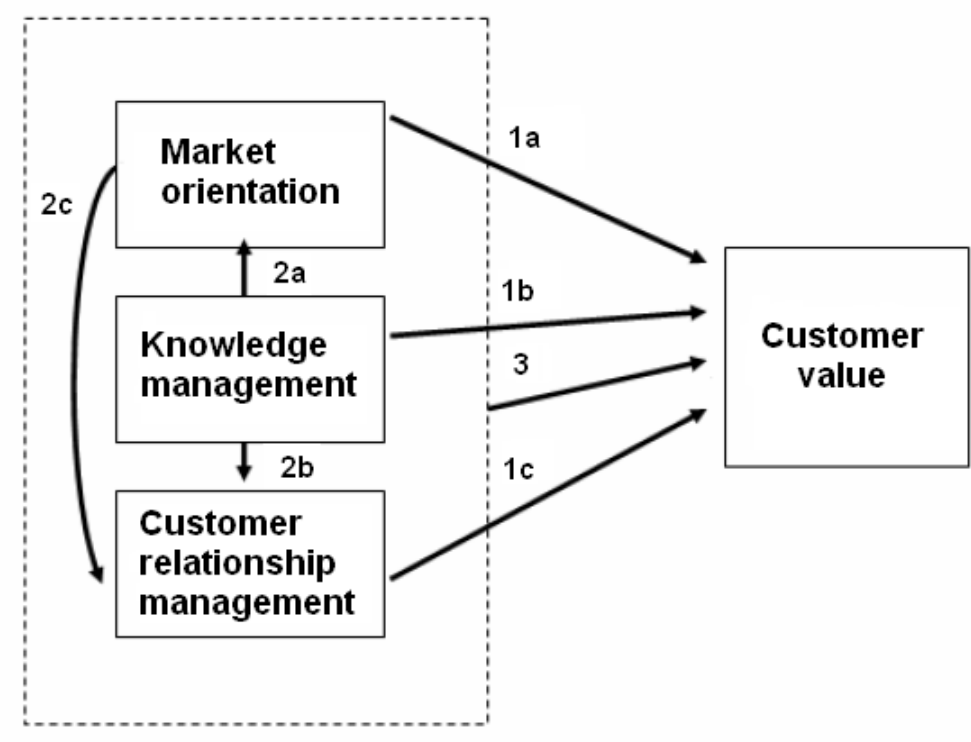

DYNAMIC CAPABILITY

Note: Arrows in the model reflect not only propositions but also knowledge flows

Source: Own elaboration 